\title{
Evaluate the physical, chemical and sensory parameters of probiotic yoghurt during storage
}

\author{
Pagthinathan, M.*, Nafees, M.S.M and Powsika, E.
}

\author{
Department of Animal Science, Faculty of Agriculture, Eastern University, Sri Lanka
}

\begin{abstract}
Dairy foods like yoghurt are the main types of food matrices supplemented with probiotic bacteria and they have a beneficial health effects among consumers. In this study, to evaluate the physico-chemical parameters and sensory attributers of probiotic added yoghurts using different concentrations $(0 \%$, $0.1 \%, 0.2 \%, 0.3 \%$ and $0.4 \%$ ) of probiotic (Bifidobacterium spp). The samples were analyzed for physico-chemical, microbiological, and sensorial properties at a week interval during storage of four weeks. The results showed that, the quality parameters such as total solids, ash, fat, reducing sugar, total sugar, $p H$ and titratable acidity did not show any significant difference $(P>0.05)$ for all types of yoghurt at during the first day of storage. Syneresis was high in $0.4 \%$ probiotic added yoghurt $(40.73 \pm 2.05 \%)$ and was lower in without probiotic yoghurt $(37.70 \pm 1.32 \%)$. During the storage period, total solids, total sugar, reducing sugar, $p H$, and titratable acidity were $(p<0.05)$ varied among the different types of yoghurt sample. At the end of storage $0.4 \%$ probiotic added yoghurt showed higher average value of total solids $(21.87 \pm 1.40 \%)$ and titratable acidity $(0.67 \pm 0.04 \%)$, while yoghurt without probiotic showed higher values of reducing sugar $(2.17 \pm 0.02 \%)$, total sugar $(10.72 \pm 0.21 \%)$ and $p H$ (4.38 \pm 0.01$)$. At the end of storage, yoghurt without probiotic showed low value of total solids $(15.80 \pm 1.93 \%)$ and yoghurt with $0.1 \%$ probiotic showed low value $(0.62 \pm 0.02 \%)$ of titratable acidity yoghurt with $0.4 \%$ probiotic showed low value of reducing sugar, total sugar and $p H$. During the storage period, dry matter, ash and titratable acidity increased with increasing concentration of probiotic in the yoghurt. Reducing sugar, total sugar and $\mathrm{pH}$ decreased with increasing concentration of probiotic. The high numbers of bacterial colony forming unit was showed during second of weeks of storage than fourth week of storage, which is lower than those without probiotic yoghurt. The sensory evaluation of the produced yogurts revealed the superiority of yogurts with $0.3 \%$ probiotic was highly preferred by consumers for their taste and overall acceptability comparison with the other types of yogurt. Finally, yogurts with $0.3 \%$ probiotic were more suitable for the consumption.
\end{abstract}

Keywords: Cow milk, Yoghurt, Probiotic, Nutritional parameters, Sensory attributes

\section{Introduction}

Fermented milk products are products that can be produced via fermentation of lactose by lactic acid bacteria. When look around the worldwide, various dairy products which are different in name but similar in content can be found and those products are an important part of human diet (Nilsson et al., 2006; Hugenholtz, 2013; Yerlikaya, 2014). Fermented dairy products are usually produced by using lactic acid bacteria and yeasts (Ozer and Kirmaci, 2010). Fermented milks have long been used as the main vehicles for probiotic strains. Less frequently, cheeses have been used for incorporation of probiotic microorganisms, but they may offer a number of advantages compared with fermented milks (Minervini et al., 2012). Cheese has higher $\mathrm{pH}$, more solid consistency, and relatively higher fat content compared with fermented milks such as yoghurt (Karimi et al., 2012).

Probiotics are defined as "live microorganisms which are believed to exert beneficial health effects in the host 
by modulating the intestinal microflora (Donkora et al., 2006). The health benefits of consuming probiotics are immune system modulation (Schlee et al., 2008), improvement of lactose intolerance (De Vrese et al., 2001), cholesterol assimilation (Liong and Shah, 2005), and antimutagenic properties (Choi et al., 2005). In addition to improving gut health, probiotics may play a beneficial role in several medical conditions, including cancer, allergies, hepatic disease, helicobacter pylori infections, urinary tract infections and hyperlipidemia (Ejtahed et al., 2011). Probiotic microorganisms are common to be ingested through dairy products, mainly fermented milk products. Bifidobacterium spp. and Lactobacillus acidophilus are by far the most important probiotics regularly added to the fermented milk (Ferdousi et al., 2013). In recent years' foods that can be shown to provide health benefits have attracted consumer interest. These foods should also fit into current lifestyles, such as good flavor and convenience with an acceptable price. Such products are commonly referred to probiotic-containing products, especially yogurt.

Yoghurt is a semi solid fermented milk product, which have highly nutritious protein-rich product obtained by fermentation of milk with S. thermophilus and L. bulgaricus. The product is highly acceptable to consumers because of its flavour and aroma, mainly attributed to acetaldehyde, and its texture (Kumar and Mishra, 2004). Nowadays, the technology of yogurt making has become more advanced, which delivers more functional health benefits as well as application of strict hygiene control along with a variety of yogurt types to suit individual tastes. At present, incorporation of probiotics like Bifidobacterium spp is a common practice in yogurt manufacture to improve the beneficial effects to the human health. Therefore, the objective of present study was to evaluate the effects of addition of probiotics (Bifidobacterium spp) on physico-chemical parameters and sensory attributes of yoghurt during the storage.

\section{Material and Methods}

\section{Raw material}

Milk was collected from Livestock farm, Eastern University, Sri Lanka throughout the study

period.

\section{Starter culture and probiotic}

The freeze-dried commercial starter yoghurt culture (DVS, CHR HANSEN, Denmark) composed of Streptococcus thermophilus (St) and Lactobacillus delbrueckii subsp. bulgaricus (Lb) and probiotic cultures: Bifidobacterium animalis subsp. (Freeze dried direct vat set CHR HANSEN, Québec, Canada) were used in this study

\section{Culture preparation and activation}

\section{a. Commercial starter culture}

Commercial starter culture was prepared by adding commercial starter $(0.33 \mathrm{~g})$ in to one liter of sterilized skim milk $(1.5 \%$ fat) and stored as $100 \mathrm{ml}$ aliquots in erlene meyer flsk at frozen temperature $\left(-20{ }^{\circ} \mathrm{C}\right)$ the cultures were thawed, activated and used as starter culture for the yoghurt preparation. Each 1 Lit of pasteurized milk was inoculated with $10 \mathrm{~mL}$ of commercial starter culture according to the manufacturer's instructions given for yoghurt production.

\section{b. Probiotic culture}

Similarly, probiotic (Bifidobacterium) culture was prepared by using $250 \mathrm{~mL}$ of sterilized skim milk (1.5\% fat) and probiotic $(0.083 \mathrm{~g})$ culture. Prepared culture was stored as $50 \mathrm{~mL}$ aliquots into to erlene - meyer flasks and freezed at -20 ${ }^{\circ} \mathrm{C}$. Before fermentation, the cultures in the to erlene - meyer flasks were thawed, activated and used as a probiotic culture 
for the yoghurt preparation. Probiotic (Bifidobacterium) culture was prepared in different concentration levels including $0 \%, 0.1 \%, 0.2 \%, 0.3 \%$ and $0.4 \%$ for yoghurt production

\section{Yoghurt production}

Milks were standardized $(2.5 \%$ milk fat $)$ by cream separator and standardized milk was pasteurized at $65{ }^{\circ} \mathrm{C}$ for $30 \mathrm{~min}$ and cooled to $37{ }^{\circ} \mathrm{C}$. The pasteurised milk was inoculated with a commercial yoghurt culture (as described in commercial starter culture) and probiotic (Bifidobacterium) culture was substituted at different concentrations levels ( $0 \%, 0.1 \%, 0.2 \%$, $0.3 \%$ and $0.4 \%$ ) as described by Manjula et al. (2012). Aliquots of inoculated milk $(125 \mathrm{~mL})$ were poured into plastic yoghurt cup, which were covered with lids and incubated at $42{ }^{\circ} \mathrm{C} 12 \mathrm{hrs}$. The plastic yoghurt cups were stored at $4 \circ \mathrm{C}$ then samples were collected at Day 1, Week 1, 2,3 and 4 interval for analyzing of physico-chemical parameters and sensory attributes.

\section{Results and Discussion}

Table 1. Physical and chemical parameters of yoghurts made from different concentration of probiotic at day one

\begin{tabular}{lccccc}
\hline Parameters & \multicolumn{5}{c}{ Treatments } \\
\hline & T1 & T2 & T3 & T4 & T5 \\
\hline Total solids & $12.03 \pm 0.25^{\mathrm{b}}$ & $12.20 \pm 1.39 \mathrm{~b}$ & $14.53 \pm 0.83^{\mathrm{ab}}$ & $15.47 \pm 2.44^{\mathrm{a}}$ & $16.87 \pm 0.21^{\mathrm{a}}$ \\
Ash & $0.60 \pm 0.00^{\mathrm{a}}$ & $0.60 \pm 0.06^{\mathrm{a}}$ & $61 . \pm 0.06^{\mathrm{a}}$ & $0.61 \pm 0.10^{\mathrm{a}}$ & $0.61 \pm 0.12^{\mathrm{a}}$ \\
Fat & $2.91 \pm 0.10^{\mathrm{a}}$ & $2.92 \pm 0.21^{\mathrm{a}}$ & $2.94 \pm 0.10^{\mathrm{a}}$ & $2.96 \pm 0.12^{\mathrm{a}}$ & $2.96 \pm 0.06^{\mathrm{a}}$ \\
Reducing & $2.40 \pm 0.04^{\mathrm{a}}$ & $2.37 \pm 0.07^{\mathrm{a}}$ & $2.36 \pm 0.03^{\mathrm{a}}$ & $2.35 \pm 0.07^{\mathrm{a}}$ & $2.33 \pm 0.05^{\mathrm{a}}$ \\
sugar & $13.53 \pm 0.84^{\mathrm{a}}$ & $13.17 \pm 0.06^{\mathrm{a}}$ & $13.10 \pm 0.26^{\mathrm{a}}$ & $13.07 \pm 0.12^{\mathrm{a}}$ & $13.03 \pm 0.06^{\mathrm{a}}$ \\
Total sugar & & & & & \\
Titratable & $0.55 \pm 0.02^{\mathrm{a}}$ & $0.55 \pm 0.06^{\mathrm{a}}$ & $0.54 \pm 0.04^{\mathrm{a}}$ & $0.54 \pm 0.04^{\mathrm{a}}$ & $0.59 \pm 0.02^{\mathrm{a}}$ \\
acidity & & & & & \\
pH & $4.70 \pm 0.01^{\mathrm{a}}$ & $4.68 \pm 0.01^{\mathrm{a}}$ & $4.66 \pm 0.01^{\mathrm{b}}$ & $4.64 \pm 0.02 \mathrm{c}^{\mathrm{b}}$ & $4.63 \pm 0.01^{\mathrm{c}}$ \\
\hline
\end{tabular}

Values are means \pm standard deviations of triplicate determination. Mean with the same letters are not significantly different at $(p<0.05)$. T1- yoghurt without probiotic T2- $0.1 \%$ probiotic added yoghurt T3- $0.2 \%$ probiotic added yoghurt T4- $0.3 \%$ probiotic added yoghurt T5- $0.4 \%$ probiotic added yoghurt

At day 1, syneresis was higher in probiotic added yogurt than without probiotic yoghurt after $1 / 2$ hr and 2 hrs. While $0.4 \%$ probiotic added yoghurt showed highest average value than other types of yoghurt (Table 2). Yoghurt with the higher probiotic had the highest level of syneresis, it may be differentiations in metabolic activities of starter cultures which cause poor consistency of the coagulum of milk and its inability to retain serum (YilmazErsan and Kurdal, 2014). 
Table 1. Syneresis of yoghurt

\begin{tabular}{llllll}
\hline \multicolumn{5}{c}{ Treatment } \\
\hline Syneresis & T1 & T2 & T3 & T4 & T5 \\
After 1/2 & $36.77 \pm 0.64^{\mathrm{b}}$ & $36.93 \pm 3.37^{\mathrm{b}}$ & $37.13 \pm 1.65^{\mathrm{b}}$ & $37.20 \pm 0.36^{\mathrm{b}}$ & $39.60 \pm 1.91^{\mathrm{a}}$ \\
$\mathrm{hr}$ & & & & & \\
After 2 hr & $37.70 \pm 1.32^{\mathrm{b}}$ & $39.23 \pm 0.59 \mathrm{ab}$ & $39.30 \pm 2.59 \mathrm{ab}$ & $39.93 \pm 2.15^{\mathrm{ab}}$ & $40.73 \pm 2.05^{\mathrm{a}}$ \\
\hline
\end{tabular}

Values are means \pm standard deviations of triplicate determination. Mean with the same letters are not significantly different at $(p<0.05)$. T1- yoghurt without probiotic T2- $0.1 \%$ probiotic added yoghurt T3- $0.2 \%$ probiotic added yoghurt T4- $0.3 \%$ probiotic added yoghurt T5- $0.4 \%$ probiotic added yoghurt.

Total solids, Ash and fat contents of yoghurts made from different concentration of probiotic during storage

Table 3 shows that total solids content of probiotic yoghurt ranged from $12.80 \%$ to $21.87 \%$ during 4 weeks of storage. At the end of the storage period, $0.4 \%$ probiotic added yoghurt showed highest $(\mathrm{p}<0.05)$ value of total solids content than yoghurt without probiotic. The increasing trend of total solids content was observed with storage period. The increase in total solids contents could be due to loss of moisture and drain out whey from the yoghurt. These results were coincided with findings of Hassan and Amjad, (2010). Very minute changes were observed in ash content in all yoghurt samples within the 4 weeks of storage period. The insignificant increase in ash contents was because of the loss of $\mathrm{CO}_{2}$ and water during charring of yoghurt samples. The end of storage average ash contents of without probiotic yoghurt and $0.4 \%$ probiotic added yoghurt were $0.73 \pm 0.46 \%$ and $0.76 \pm 0.20 \%$, respectively. The results are in agreement with the findings of Hassan and Amjad, (2010) who reported the ash value of probiotic yoghurt as within the range. Fat content were relatively constant during storage, which suggests that probiotic did not affect significantly

Table 3. Changes of total solids, ash and fat content in yoghurt during storage

\begin{tabular}{llccll}
\hline Trt & Parameters & Week 1 & Week 2 & Week 3 & Week 4 \\
\hline T1 & Total solids (\%) & $12.80 \pm 0.53^{\mathrm{e}}$ & $13.00 \pm 1.39^{\mathrm{e}}$ & $14.33 \pm 1.50^{\text {ed }}$ & $15.80 \pm 1.93^{\mathrm{bcde}}$ \\
& Ash (\%) & $0.60 \pm 0.12^{\mathrm{b}}$ & $0.65 \pm 0.31^{\mathrm{b}}$ & $0.69 \pm 0.35^{\mathrm{a}}$ & $0.73 \pm 0.46^{\mathrm{a}}$ \\
& Fat (\%) & $2.93 \pm 0.06^{\mathrm{a}}$ & $2.93 \pm 0.15^{\mathrm{a}}$ & $2.93 \pm 0.15^{\mathrm{a}}$ & $2.92 \pm 0.00^{\mathrm{a}}$ \\
\hline T2 & Total solids (\%) & $12.93 \pm 1.33^{\mathrm{e}}$ & $14.80 \pm 1.11^{\text {cde }}$ & $15.53 \pm 0.31^{\mathrm{bcde}}$ & $16.53 \pm 2.73^{\mathrm{bcd}}$ \\
& Ash (\%) & $0.61 \pm 0.12^{\mathrm{b}}$ & $0.66 \pm 0.31^{\mathrm{b}}$ & $0.70 \pm 0.12^{\mathrm{a}}$ & $0.74 \pm 0.20^{\mathrm{a}}$ \\
& Fat (\%) & $2.94 \pm 0.15^{\mathrm{a}}$ & $2.93 \pm 0.06^{\mathrm{a}}$ & $2.92 \pm 0.12^{\mathrm{a}}$ & $2.92 \pm 0.12^{\mathrm{a}}$ \\
\hline T3 & Total solids (\%) & $14.60 \pm 0.60^{\text {de }}$ & $15.20 \pm 1.25^{\mathrm{bcde}}$ & $16.00 \pm 1.06^{\mathrm{bcde}}$ & $17.87 \pm 1.33^{\mathrm{cb}}$ \\
& Ash (\%) & $0.62 \pm 0.12^{\mathrm{c}}$ & $0.67 \pm 0.31^{\mathrm{b}}$ & $0.71 \pm 0.12^{\mathrm{ab}}$ & $0.75 \pm 0.20^{\mathrm{a}}$ \\
& Fat (\%) & $2.95 \pm 0.15^{\mathrm{a}}$ & $2.95 \pm 0.06^{\mathrm{a}}$ & $2.94 \pm 0.06^{\mathrm{a}}$ & $2.93 \pm 0.10^{\mathrm{a}}$ \\
\hline T4 & Total solids (\%) & $15.93 \pm 2.34^{\mathrm{bcde}}$ & $16.33 \pm 1.40^{\mathrm{bcd}}$ & $17.40 \pm 0.40^{\mathrm{bcd}}$ & $21.47 \pm 3.11^{\mathrm{a}}$ \\
& Ash (\%) & $0.63 \pm 0.12^{\mathrm{c}}$ & $0.67 \pm 0.31^{\mathrm{b}}$ & $0.70 \pm 0.12^{\mathrm{ab}}$ & $0.75 \pm 0.20^{\mathrm{a}}$ \\
& Fat (\%) & $2.97 \pm 0.15^{\mathrm{a}}$ & $2.97 \pm 0.15^{\mathrm{a}}$ & $2.97 \pm 0.06^{\mathrm{a}}$ & $2.95 \pm 0.10^{\mathrm{a}}$ \\
\hline T5 & Total solids (\%) & $17.10 \pm 2.10^{\mathrm{bcd}}$ & $17.83 \pm 0.78^{\mathrm{bc}}$ & $18.20 \pm 2.62^{\mathrm{b}}$ & $21.87 \pm 1.40^{\mathrm{a}}$ \\
& Ash (\%) & $0.64 \pm 0.12^{\mathrm{c}}$ & $0.68 \pm 0.31^{\mathrm{b}}$ & $0.72 \pm 0.12^{\mathrm{ab}}$ & $0.76 \pm 0.20^{\mathrm{a}}$ \\
& Fat (\%) & $2.98 \pm 0.15^{\mathrm{a}}$ & $2.97 \pm 0.12^{\mathrm{a}}$ & $2.97 \pm 0.15^{\mathrm{a}}$ & $2.96 \pm 0.17^{\mathrm{a}}$ \\
\hline
\end{tabular}

Values are means \pm standard deviations of triplicate determination. Mean with the same letters are not significantly different at $(p<0.05)$. T1- yoghurt without probiotic T2- $0.1 \%$ probiotic added yoghurt T3$0.2 \%$ probiotic added yoghurt T4- $0.3 \%$ probiotic added yoghurt T5- $0.4 \%$ probiotic added yoghurt. 
Reducing sugar and total sugar in yoghurt during the storage period

The result showed that reducing sugar and total sugar was $(P<0.05)$ decreased throughout the storage period (Table 4). At the end of the storage period $0.4 \%$ probiotic added yoghurt showed lowest value of reducing sugar $(2.05 \pm 0.01)$ than yoghurt without probiotic $(2.27 \pm 0.00)$. It might be due to the conversion of lactose into lactic acid with time of storage by lactic acid bacteria. These results were coincided with findings of Metry and Owayss, (2009). Similarly, during the storage period $0.4 \%$ probiotic added yoghurt showed lowest value of total sugar compare to other all types of yoghurt samples. This may be due to the concentration of probiotic hydrolyzed the polysaccharides oxidation of sugars present in yoghurt.

Table 4. Changes of reducing sugar and total sugar in yoghurt during storage

\begin{tabular}{llllll}
\hline Trt & Parameters & Week 1 & Week 2 & Week 3 & Week 4 \\
\hline T1 & Reducing sugar (\%) & $2.43 \pm 0.04^{\mathrm{a}}$ & $2.35 \pm 0.04^{\mathrm{b}}$ & $2.22 \pm 0.03^{\text {efgh }}$ & $2.17 \pm 0.02^{\mathrm{hij}}$ \\
& Total sugar (\%) & $13.33 \pm 0.12^{\mathrm{a}}$ & $13.11 \pm 0.10^{\mathrm{ab}}$ & $11.40 \pm 0.10^{\mathrm{e}}$ & $10.72 \pm 0.21^{\mathrm{gh}}$ \\
\hline T2 & Reducing sugar (\%) & $2.30 \pm 0.05^{\mathrm{bc}}$ & $2.25 \pm 0.01^{\text {cdef }}$ & $2.22 \pm 0.02^{\text {efgh }}$ & $2.15 \pm 0.04^{\mathrm{ij}}$ \\
& Total sugar (\%) & $13.00 \pm 0.10^{\mathrm{bc}}$ & $12.95 \pm 0.15^{\mathrm{bc}}$ & $11.11 \pm 0.13^{\mathrm{f}}$ & $10.50 \pm 0.24^{\mathrm{hi}}$ \\
\hline T3 & Reducing sugar (\%) & $2.29 \pm 0.02^{\mathrm{cd}}$ & $2.24 \pm 0.03^{\text {def }}$ & $2.21 \pm 0.00^{\text {efgh }}$ & $2.12 \pm 0.00^{\mathrm{jk}}$ \\
& Total sugar (\%) & $12.93 \pm 0.03^{\mathrm{bc}}$ & $12.82 \pm 0.06^{\mathrm{c}}$ & $11.07 \pm 0.12^{\mathrm{f}}$ & $10.42 \pm 0.38^{\mathrm{i}}$ \\
\hline T4 & Reducing sugar (\%) & $2.29 \pm 0.09^{\mathrm{cd}}$ & $2.24 \pm 0.02^{\text {defg }}$ & $2.20 \pm 0.01^{\text {fghi }}$ & $2.08 \pm 0.01^{\mathrm{kl}}$ \\
& Total sugar(\%) & $12.91 \pm 0.04^{\mathrm{bc}}$ & $12.75 \pm 0.06^{\mathrm{c}}$ & $10.98 \pm 0.03^{\mathrm{fg}}$ & $10.34 \pm 0.12^{\mathrm{i}}$ \\
\hline T5 & Reducing sugar (\%) & $2.27 \pm 0.00^{\mathrm{cde}}$ & $2.23 \pm 0.05^{\text {defgh }}$ & $2.18 \pm 0.03^{\mathrm{ghij}}$ & $2.05 \pm 0.01^{1}$ \\
& Total sugar $(\%)$ & $12.83 \pm 0.02^{\mathrm{bc}}$ & $11.69 \pm 0.08^{\mathrm{d}}$ & $10.87 \pm 0.16^{\mathrm{fg}}$ & $10.32 \pm 0.23^{\mathrm{i}}$ \\
\hline
\end{tabular}

Values are means \pm standard deviations of triplicate determination. Mean with the same letters are not significantly different at $(p<0.05)$. T1- yoghurt without probiotic T2- $0.1 \%$ probiotic added yoghurt T3- $0.2 \%$ probiotic added yoghurt T4- $0.3 \%$ probiotic added yoghurt T5- $0.4 \%$ probiotic added yoghurt.

\section{pH and titratable acidity in yoghurt during the storage period}

$\mathrm{pH}$ and titratable acidity presented the same trend in all types of yogurt groups during storage period (Table 5). During storage, all yoghurt samples showed continued decreased in $\mathrm{pH}$ and end of storage, average $\mathrm{pH}$ value of without probiotic yoghurt and $0.4 \%$ probiotic added yoghurt were 4.38 and 4.15, respectively. The reduction in $\mathrm{pH}$ can be due to the breakdown of lactose into lactic acid. Probiotic and starter cultures yielded a different $\mathrm{pH}$ profile with the passage of time. The lag time for $\mathrm{pH}$ decreases during storage and this reflected the acidification rate of the culture involved. These results agree with results reported by Behrad et al. (2009), who mentioned that the $\mathrm{pH}$ for all yoghurts reduced from the initial values of 4.5 to 4.09 at 28 days of storage

The average acidity of without probiotic yoghurt was $0.65 \%$ and $0.4 \%$ probiotic added yoghurt was $0.67 \%$. The results showed that acidity tends to increase in all types of yoghurt during storage period. The changes in titrable acidity of yoghurt could be a fermentation process by microorganism and degradation of lactose into lactic acid. These results are in agreement with the results of Hassan, A. and Amjad, (2010). 
Table 5. Changes of $\mathrm{pH}$ and titratable acidity in yoghurt during storage

\begin{tabular}{clllll}
\hline Trt & Parameters & Week 1 & Week 2 & Week 3 & Week 4 \\
\hline T1 & $\mathrm{pH}$ & $4.68 \pm 0.01^{\mathrm{a}}$ & $4.60 \pm 0.01^{\mathrm{b}}$ & $4.44 \pm 0.03^{\mathrm{e}}$ & $4.38 \pm 0.01^{\mathrm{hi}}$ \\
& Titratable acidity (\%) & $0.56 \pm 0.02^{\mathrm{ab}}$ & $0.60 \pm 0.02^{\mathrm{ab}}$ & $0.62 \pm 0.02^{\mathrm{ab}}$ & $0.65 \pm 0.00^{\mathrm{ab}}$ \\
\cline { 2 - 5 } T2 & $4.62 \pm 0.01^{\mathrm{b}}$ & $4.58 \pm 0.01^{\mathrm{c}}$ & $4.40 \pm 0.01 \mathrm{fg}$ & $4.28 \pm 0.0^{1 \mathrm{k}}$ \\
& TH & $0.58 \pm 0.07^{\mathrm{b}}$ & $0.59 \pm 0.04^{\mathrm{ab}}$ & $0.61 \pm 0.04^{\mathrm{ab}}$ & $0.62 \pm 0.02^{\mathrm{ab}}$ \\
\cline { 2 - 6 } T3 & $\mathrm{pH}$ & $4.60 \pm 0.01^{\mathrm{b}}$ & $4.56 \pm 0.01^{\mathrm{c}}$ & $4.39 \pm 0.01 \mathrm{gh}$ & $4.22 \pm 0.01^{1}$ \\
& Titratable acidity (\%) & $0.59 \pm 0.06^{\mathrm{ab}}$ & $0.60 \pm 0.06^{\mathrm{ab}}$ & $0.62 \pm 0.06^{\mathrm{ab}}$ & $0.65 \pm 0.04^{\mathrm{ab}}$ \\
\cline { 2 - 6 } T4 & $\mathrm{pH}$ & $4.58 \pm 0.01^{\mathrm{c}}$ & $4.53 \pm 0.02^{\mathrm{d}}$ & $4.36 \pm 0.01^{\mathrm{i}}$ & $4.20 \pm 0.01^{1}$ \\
& Titratable acidity (\%) & $0.58 \pm 0.07^{\mathrm{b}}$ & $0.59 \pm 0.04^{\mathrm{ab}}$ & $0.64 \pm 0.04^{\mathrm{ab}}$ & $0.65 \pm 0.07 \mathrm{ab}$ \\
\cline { 2 - 6 } T5 & $\mathrm{pH}$ & $4.52 \pm 0.02^{\mathrm{d}}$ & $4.42 \pm 0.01^{\mathrm{ef}}$ & $4.31 \pm 0.02^{\mathrm{j}}$ & $4.15 \pm 0.04^{\mathrm{m}}$ \\
& Titratableacidity (\%) & $0.61 \pm 0.00^{\mathrm{ab}}$ & $0.62 \pm 0.02^{\mathrm{ab}}$ & $0.65 \pm 0.04^{\mathrm{ab}}$ & $0.67 \pm 0.04^{\mathrm{a}}$ \\
\hline
\end{tabular}

Values are means \pm standard deviations of triplicate determination. Mean with the same letters are not significantly different at $(p<0.05)$. T1- yoghurt without probiotic T2- $0.1 \%$ probiotic added yoghurt T3- $0.2 \%$ probiotic added yoghurt T4- $0.3 \%$ probiotic added yoghurt T5- $0.4 \%$ probiotic added yoghurt.

\section{Microbial analysis of yoghurt during storage}

The bacterial analysis of the yogurts showed that the decreasing colony forming unit during storage period at $4^{\circ} \mathrm{C}$. After two weeks of storage without probiotic yogurt and $0.4 \%$ probiotic added yoghurt showed $5.76^{*} 10^{5} \mathrm{CFU} / \mathrm{ml}$ and $8.13^{*} 10^{5}$ $\mathrm{CFU} / \mathrm{ml}$ colony forming unit, respectively. After 4 weeks of storage, in all cases the bacterial colony forming units were declined. At $4^{\text {th }}$ weeks storage without probiotic yoghurt and $0.4 \%$ probiotic added yoghurt showed $\left(4.13^{*} 10^{5} \mathrm{CFU} / \mathrm{ml}\right)$ and $5.76^{*} 10^{5}$ colonies forming unit, respectively. That because the growth rate of bacteria depends on the amount of lactic acid produced, and thus on the $\mathrm{pH}$. The bacteria grow faster at higher $\mathrm{pH}$ value. Therefore, at 4 weeks of storage, the amount of lactic acid increased and $\mathrm{pH}$ decreased that affected to the decrease of total bacteria in yogurt product (Sabbah et al., 2009).

\section{Sensory evaluation}

Organoleptic evaluation was carried out to assess organoleptic and the quality characteristic of yoghurts prepared from different concentrations of probiotic. The panelist from various groups were served with the samples to evaluate certain attributes. The results of sensory evaluation of yoghurt on the basis of texture, taste, colour, flavour, overall acceptability are summarized in Fig.. 1. All mean scores for the different sensory attributes of the all yoghurts were within the commercially acceptable range (4-9 scores) recommended for yoghurt by the nine points scheme (Resurreccion, 1998). At Day 1, results showed that there were no significant differences $(\mathrm{P}>0.05)$ in all attributes for different types yoghurt.

During storage, sensory attributes of the yoghurt sample were observed that without probiotic yoghurt for texture, colour and flavor were mostly preferred by panelist. On the other hand, sensory attributes like taste and overall acceptability were high in $0.3 \%$ probiotic added yoghurt while texture, colour and flavor were preferred by yoghurt made from without probiotic yoghurt. In general, all sensory attribute scores of samples increased during storage of up to 2 weeks and thereafter decreased for all attributes. This could be associated with development of acidity and decreases in acetaldehyde contents. 


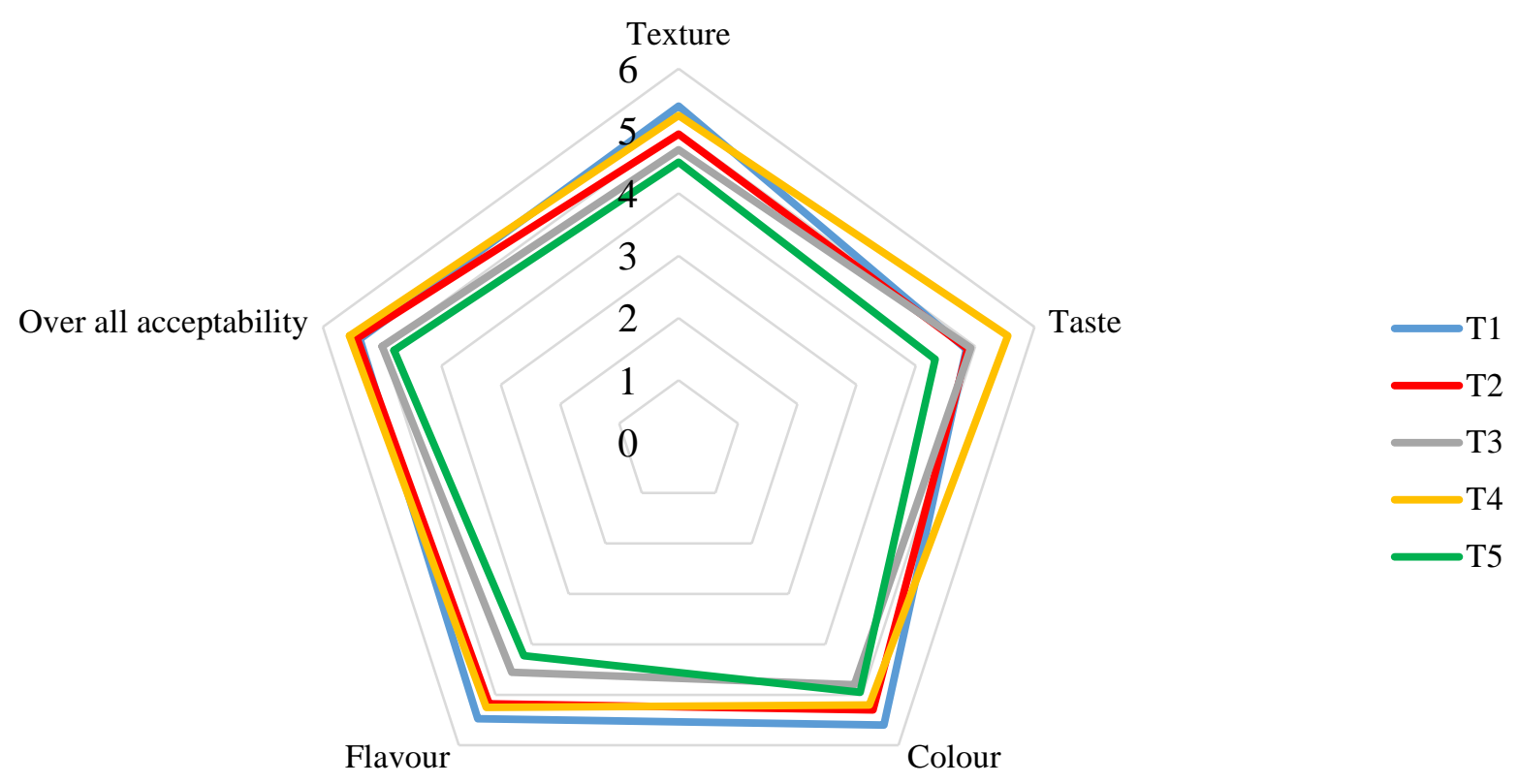

T1- yoghurt without probiotic T2- $0.1 \%$ probiotic added yoghurt T3- $0.2 \%$ probiotic added yoghurt T4$0.3 \%$ probiotic added yoghurt T5- $0.4 \%$ probiotic added yoghurt

\section{Fig. 1: Variation in sensory attributes during storage period}

\section{Conclusion}

The study revealed that different concentration of probiotic added yoghurt had no significant effects on the ash, fat, reducing sugar, total sugar and titratable acidity at day 1 but total solids, $\mathrm{pH}$ and syneresis were gradually increased with increasing concentration of probitics.

During the storage period, total solids and titratable acidity were increasing while total sugar, reducing sugar and $\mathrm{pH}$ were decreased. At the end of storage $0.4 \%$ probiotic added yoghurt shows higher value of total solids and titratable acidity contents. On the other hand, yoghurt without probiotic shows higher value for reducing sugar, total sugar and $\mathrm{pH}$. Sensory attributes, such as texture, taste, flavour, colour and overall acceptability, varied among the different types of yoghurt. Finally, taste and overall acceptability were preferred by panelist yoghurt made from $0.3 \%$ added probiotic yoghurt while texture, colour and flavor were preferred by yoghurt made from without probiotic yoghurt. Finally, yogurts with $0.3 \%$ probiotic were more suitable for the consumption.

\section{References}

Al-Kadamany, E., Khattar, M., Haddad, T., and Toufeili, I. 2003. "Estimation of Shelf Life of Concentrated Yoghurt by Monitoring Selected Microbiological and Physiological Changes during Storage." Lebensmittel-Wissenschaft and Technologie, 36: 407-414.

3.9.1 Akpapunam, M. A. and SefaDedeh, S. (1995). Traditional lactic acid fermentation, malt addition and quality development in maize-cowpea weaning blends. Food and Nutrition Bulletin, 16: 7580. 
AOAC. (1995). Fat, lactose, protein and solids in milk. Official Methods of analysis. AOAC

Official Method 972.16. Washington, DC, USA: Association of Official Analytical Chemists.

Behrad, S., Yusof, M. Y., Goh, K. L. and Baba, A. S. (2009). "Manipulation of Probiotics Fermentation of Yogurt by Cinnamon and Licorice: Effects on Yogurt Formation and Inhibition of Helicobacter Pylori Growth in Vitro." World Academy of Science, Engineering and Technol ogy, 60: 590-594.

British Standards Institution (BSI). (1995). Gerber method for the determination of fat in milk and milk products. British Standard 696. London: British Standards Institution

Choi, S. S., Kim, Y., Han, K. S., You, S., Oh, S. and Kim, S. H. (2006). Effects of Lactobacillus strains on cancer cell proliferation and oxidative stress in vitro. Letters in applied microbiology, 42(5): 452-458.

De Vrese, M., Stegelmann, A., Richter, B., Fenselau, S., Laue, C. and Schrezenmeir, J. (2001). Probiotics-compensation for lactase insufficiency. The American journal of clinical nutrition, 73(2) :421-429.

Donkora, O.N., Henrikssonb, A., Vasiljevica, T. and Shaha, N.P. (2006). Effect of acidification on the activity of probiotics in yoghurt during cold storage. International Dairy Journal, 16 : 1181-1189.

Ejtahed, H. S., Mohtadi-Nia, J., Homayouni-Rad, A., Niafar, M., AsghariJafarabadi, M., Mofid, V. and AkbarianMoghari, A. (2011). Effect of probiotic yogurt containing Lactobacillus acidophilus and Bifidobacterium lactis on lipid profile in individuals with type 2 diabetes mellitus. Journal of Dairy Science, 94(7): 3288-3294.
Ferdousi, R., Rouhi, M., Mohammadi, R., Mortazavian, A. M., Khosravi-Darani, K. and Homayouni Rad, A. (2013). Evaluation of probiotic survivability in yogurt exposed to cold chain interruption. Iranian Journal of Pharmaceutical Research, 12: 139144.

Hassan, A. and Amjad, I. (2010). Nutritional evaluation of yoghurt prepared by different starter cultures and their physiochemical analysis during storage. African Journal of Biotechnology, 9(20): 29132917.

Hugenholtz, J. (2013). Traditional biotechnology for new foods and beverages. Current Opinion in Biotechnology, 24(2): 155-159.

Karimi, R., Mortazavian, A. M. and Karami, M. (2012). Incorporation of Lactobacillus casei in Iranian ultrafiltered Feta cheese made by partial replacement of $\mathrm{NaCl}$ with $\mathrm{KCl}$. Journal of Dairy Science, 95(8): 4209-4222.

Kodaka, H., Mizuochi, S., Teramura, H., and Nirazuka, T. 2005. "Comparison of the Compact Dry TC Method with the Standard Pour Plate Method (AOAC Official Method 966.23) for Determining Aerobic Colony Counts in Food Samples. Journal of AOAC International, 88 (6): 170213.

Kumar, $\mathrm{P}$ and Mishra, H. N. (2004).Yoghurt powder-a review of process Technology, storage and utilization.Food and Bioproducts Processing, 82(C2): 133-142.

Liong, M. T. and Shah, N. P. (2005). Acid and bile tolerance and cholesterol removal ability of lactobacilli strains. Journal of dairy science, 88(1):55-66.

Manjula, K., Viswanath, C. and Suneetha, C. (2012). Physico-Chemical, Sensory and Microbial Quality of Yoghurt Fortified with Sapota Pulp. International Journal of 
Material Sciences and Chemistry, 1(1): 004006.

Metry, W. A., and Owayss, A. A. (2009). Influence of incorporating honey and royal jelly on the quality of yoghurt during storage. Egyptian Journal of Food Science, 37 :115-131.

Minervini, F., Siragusa, S., Faccia, M., Dal Bello, F., Gobbetti, M. and De Angelis, M. (2012). Manufacture of Fior di Latte cheese by incorporation of probiotic lactobacilli. Journal of Dairy Science, 95(2): 508-520.

Nilsson, L. E., Lyckand, S., and Tamime, A. Y. (2006). Production of drinking products. In A. Y. Tamime (Ed.), Fermented milks. Oxford: Blackwell Science. http://dx.doi.org/10.1002/9780470995501. ch5.

Ozer, B. H., and Kirmaci, H. A. (2010). Functional milks and dairy beverages. International Journal of Dairy Technology, 63(1): 1-15.
Resurreccion, A. V. A. 1998. Consumer Sensory Testingfor Product Development. Gaithersburg: Aspen Publications Inc..

Sabbah, M., Legowo, A. M. and Pramono, Y. B. (2012). The effect of different ratio of bacteria (Lactobacillus Bulgaricus Streptococcus Thermophilus and Bifidobacterium Longum. atcc15707) on characteristics of yogurt at different storage period. Journal of Applied Food Technology, 1 (2): 32 -38.

Schlee, M., Harder, J., Köten, B., Stange, E. F., Wehkamp, J. and Fellermann, K. (2008). Probiotic lactobacilli and VSL\# 3 induce enterocyte $\beta$-defensin 2. Clinical and Experimental Immunology, 151(3): 528-535.

Yerlikaya, O. (2014). Starter cultures used in probiotic dairy product preparation and popular probiotic dairy drinks. Food science technology campinas, 34(2): 221-229.

Yilmaz-Ersan, L.and Kurdal, E. (2014). The Production of Set-Type-Bio-Yoghurt with Commercial Probiotic Culture. International Journal of Chemical Engineering and Applications, 5(5): 402-408. 